\title{
Imagining the Twentieth Century: Retrospective, Myth, and the Colonial Question
}

\section{David Bruce MacDonald, Otago University}

As the twentieth century drew to a close, retrospectives entered into fashion, be they boxed-set or abridged, chronological descriptions, or fin de siecle memoirs. Written by some of today's leading historians and political scientists, these have attempted, by and large, to portray the twentieth century as the most atrocious in human history, in terms of totalising ideologies, bloodshed, terror, and mass death. While providing useful coverage of twentieth century events, retrospectives have a tendency to downplay or ignore conflict and conquest in earlier centuries. The nineteenth century emerges as an age of moral values, hope, progress and enlightenment - an era squandered only from World War I onwards, leading inexorably to Auschwitz, Vietnam, Cambodia, and Yugoslavia.

This article seeks to explore how and why the twentieth century has been cast as the most atrocious. I also problematise the creation of a nineteenth century foil, a moral opposite and other, which has often been used to create a false before-and-after portrayal of historical events. Historian Will Durant calculated recently that there has only been a 29-year period in all of human history during which there was no warfare in progress somewhere in the world (Hynes 1998, xi). Yet, a form of historical amnesia 
seems to pervade western scholarship, whereby the twentieth century emerges as decisive break from the past, an anomaly - or 'very unpleasant surprise’ (Glover 1999, $3)$.

In 1822, Ernest Renan famously observed that 'the essential element of a nation is that all its individuals must have many things in common but it must also have forgotten many things.’ Arguably, in an effort to retain positive views about the past, societies deliberately forget uncomfortable knowledge, which then becomes a series of 'open secrets' known by everyone but not discussed. Cohen has described a form of 'social amnesia': 'a mode of forgetting by which a whole society separates itself from its discreditable past record’ (Buckley-Zistel 2006, 132-3).

Previous centuries, however, were hardly ideal, neither for Europeans nor their colonial subjects. Colonialism in earlier centuries saw large percentages of indigenous peoples killed; there were more examples of successfully implemented genocide in the eighteenth and nineteenth centuries than afterwards. Without downplaying the reality of twentieth century horrors (or their death totals), there needs to be space for resurrecting the past. This article will critically examine twentieth century retrospectives, contrasting them with recent critiques of colonialism in the nineteenth century and before. I critique recent Eurocentric scholarship for deliberately ignoring many of the negative aspects of western history, even reconstructing time in such as way as to privilege European history and events over those of other continents and peoples. This underlines the trend, as Chakrabarty has noted, of putting 'Europe first, the rest of the world later' (2000).

\section{Approaching History: Conflicting Perspectives}

How history is approached is often as important as the events themselves. Hayden White has attacked the idea that histories or retrospectives are authentic representations of actual events, with only 'certain rhetorical flourishes or poetic effects' to distract readers from the truth of what they are reading (1987, x; 24). Rather, White argues that all forms of historical narrative, be they 'annals,' 'chronicles,' or 'history proper' 
(according to his taxonomy), are subject to a process of 'narrativising.' Here, historians try to create a story from the 'real events' of history, complete with a beginning and an end, and some type of moral lesson. As White, argues, the biases, desires and fantasies of the historian cannot be considered separate from the events they are describing. Which events are chosen and how they are presented will depend on a number of very personal factors, expressed through a process of 'narrativising' (White 1987, 4).

This argument about 'narrativising' was later raised by Campbell, in his alternative reading of the first Gulf War. He describes how policy makers, historians and others interpret events and craft a 'story,' with an 'ordered plot,' 'cast of characters,' 'attributable motivations,' and 'lessons for the future’ (1993, 7; 26-7). Historical accounts are often little more than one interpretation and organisation of a myriad of events, arranged according to the bias and ideals of the 'narrator.' White and Campbell both laudably attempt to examine the method by which a series of chronological events eventually emerge as a closed historical juncture, with a beginning and an end, and a series of moral lessons of good and evil. Through such a reading, retrospectives on the twentieth century involve a set of judgements, normative redefinitions of the past, and prescriptions for the future. We learn lessons from them: 'don't follow charismatic leaders'; 'beware of totalising ideologies'; 'democracy is the best defence against violence and bloodshed'; and so on. Retrospectives tell us where we went wrong, and why. Finding an 'other' or a foil in the nineteenth century provides a useful contrast if we are to moralise about twentieth century depravity.

A contrary argument is given by Hobsbawm, who is quick to dismiss postmodernism's relativism and its discursive view of history. His primary attack concerns those who generate postmodern scholarship. These, he argues, 'see themselves as representing collectivities or milieux marginalized by the hegemonic culture of some group ... whose claim to superiority they contest. But it is wrong.' Postmodernism's relativism, according to Hobsbawm, allows for, 'no clear distinction between what is true and what I feel to be true’ (Hobsbawm 1997, 271; Jacoby 1999, 118-120). In contradistinction to White, Hobsbawm promotes history as a telling of the facts - an account of what really 
happened. 'Without the distinction between what is real and what is not,' he advances, 'there is no history' (Hobsbawm 1997, viii). Facts cannot be invented, 'Either Elvis Presley is dead or he isn't. The question can be unambiguously answered on the basis of evidence, insofar as reliable evidence is available’ (Hobsbawm 1997, 6).

Certainly there are indisputable facts, but there are also biases in factual accounts, making some accounts more plausible than others. And sometimes, 'facts' are disputed - sometimes rumours of Elvis Presley’s death are greatly exaggerated. Take for example Hobsbawm’s straightforward and unambiguous analysis of Kosovo. Here, 'Few of the ideologies of intolerance are based on simple lies or fictions for which no evidence exists. After all, there was a battle of Kosovo in 1389, the Serb warriors and their allies were defeated by the Turks, and this did leave scars on the popular memory of the Serbs ...' $(1997,6)$. On the surface, this statement is relatively unproblematic. However — Serbian defeat at Kosovo in 1398 is not an indisputable fact-historical records allow for a wide variety of interpretations. Marriott insists that the Serbs lost decisively, Judah advances that the Serbs may have actually won the Battle, while Malcolm's definitive account advances that the Battle was a draw, neither side having clinched decisive victory (Marriott 1930, 65; Judah 1997, 31; Malcolm 1998, 75-9).

I use this rather mundane example to demonstrate that 'facts' as we know them are not always givens, nor are an historian's motivations always obvious. While motives may be relatively benign, historians can exclude much, in their need for concision, or due to their ignorance of some aspects of history. Perhaps more likely - historians desire to have their histories 'fit' into a neat framework, conferring their own view of the world. Roberts's The Twentieth Century, offers a good example of such a process in action. In his introduction, Roberts adopts a mixture of apology and defiance, when he argues 'The history of the twentieth century has therefore to be approached with (what is sometimes deplored) a "Eurocentric” stance. In many ways, the world actually was centred on Europe when the twentieth century began. Much of that century's story is of how and why that ceased to be true before it ended’ (Roberts 1999, 38). Here, European history takes precedence because the world was 'centred on it' - non-European history 
is devalued and marginalised before the book even begins.

\section{Creating a New Twentieth Century}

In coming to terms with twentieth century 'narratives,' it is useful to look at how time can be reinterpreted in light of an author's personal viewpoint. For some, writing history is little more than, 'measuring an endless piece of string with a ruler.' Centuries are arbitrary inventions, 'just a distance between two chosen points’ (Roberts 1999, 3). For others, centuries are defined by wars, revolutions, and other major transformations, which encapsulate the mood or overall 'feel' of a century, and come to symbolise it. Thus emerges the concept of 'long' and 'short' centuries. Lukacs's 'short century' is but 75 years in length—running from 1914 to 1989 (Lukacs 1993, 1) —as are those of Grenville $(1994,1)$ and Hobsbawm.

For Lukacs as for others, time and its division into centuries is purely a European affair, established primarily by military victories and defeats. The 'real' nineteenth century only begins after Napoleon's defeat at Waterloo in 1815, and ends with World War I, a century of 99 years. The eighteenth century is 126 years long, beginning with 'the world wars between England and France,' and ending with Waterloo. The 101-year seventeenth century begins with the defeat of the Spanish Armada in 1588, and closes with the rise of France as England's chief enemy in 1689 (Lukacs 1993, 1-2). But such demarcations depend on individual choice. Grenville offers alternatives: a nineteenth century starting with the French Revolution of 1789, with the beginnings of the twentieth century in 1871 (with German unification) or 1890 (with the beginnings of German Weltpolitik) (1994, 1). Such divisions are as inherently Eurocentric as their authors. After all, World War I had little direct impact in Asia, Africa, or Latin America. Similarly, the collapse of Communism in 1989 had significantly greater repercussions within Europe than outside it. We can also criticise the short century’s reductionism - it becomes little more than the clash between Communism and liberal democracy (Ponting 1998, 4).

Hobsbawm's short century epitomises such criticisms. His is effectively encapsulated 
by the rise and fall of Soviet communism, which, he asserts, 'forms a coherent historical period’ (Hobsbawm 1994, 5). However, like Lukacs and Grenville, personal motivations, such as his long-term affiliations with Communism, have much to do with his choice of dates (Conquest 2000, 10-11). Conquest has noted Hobsbawm's 'addiction to Marxism,' as well as his, 'if not unqualified approval of, then undisguised preference for, Communist regimes' (Conquest 2000, 50). In these cases, White’s narrativity is obvious - even the division of centuries owes much to the motivations and desires of the individual historian.

\section{The Twentieth Century as Squandered Utopia}

The most prevalent portrayal of the twentieth century is one of squandered legacy - the belief that the wonders of the nineteenth century were forever tarnished by the horrors of technology, war, and totalising ideologies. In The Age of Extremes, the twentieth century emerges as the worst in human history, 'Not only because it was without doubt the most murderous century of which we have record, both by the scale, frequency and length of warfare which filled it ... but also by the unparalleled scale of the human catastrophes it produced, from the greatest famines in history to systemic genocide' (Hobsbawm 1994, 13). Glover's Humanity: A Moral History of the $20^{\text {th }}$ Century, advances essentially the same view. He too sees the century as one of dashed expectations,

\footnotetext{
At the start of the century there was optimism, coming from the Enlightenment that the spread of a humane and scientific outlook would lead to the fading away, not only of war, but also of other forms of cruelty and barbarism. They would fill the chamber of horrors in the museum of our primitive past. In light of these expectation, the century of Hitler, Stalin, Pol Pot and Saddam Hussein was likely to be a surprise. Volcanoes thought extinct turned out not to be (Glover 1999, 6).
}

Similar portrayals can be found throughout this body of contemporary literature.

Gilbert's A History of the Twentieth Century opens with the following statement, 'The twentieth century has witnessed some of humanity's greatest achievements and some of its worst excesses’ (Gilbert 1997, 1). Howard and Louis’s Oxford History portrays the century’s beginning as a 'paradoxical combination of hope and fear.' There was hope for a 'new Golden Age,’ of ‘scientific discoveries and technological developments.' 
Nevertheless, 'fear arose from the apparent disintegration of traditional values and social structures, both secular and religious ... and from the prospect that the world was therefore confronting a future in which only the strongest and the most ruthless would survive’ (Howard and Louis 1998, xix).

Violence is often premised on the irrationality of ideology in the twentieth century, and the abandonment of Christianity and its moral precepts. Furet commented that, 'in the nineteenth century, History replaces God as the all powerful force in the destiny of men, but only in the twentieth century do we see the political madness caused by this substitution’ (Finkielkraut 1998, 63). For Brzezinski, Nazism and Communism tried to, 'usurp the role of the world's great religions' - but produced fanaticism and 'megadeaths' instead (1995, 34). For Coker, Nazism was based on 'an irrational ideology,' one which was 'deeply antagonistic to the values of the Enlightenment' (1998, 169).

For many retrospectives, a focus on World Wars I and II is an obvious starting point. Popular consensus in the literature suggests that World War I inaugurates the 'short' century, through its surprising mix of death and destruction, setting the stage for further conflict as the century progresses. Amid Hobsbawm's four reasons for the violence of the twentieth century is, 'the limitless sacrifices which governments imposed on their own men as they drove them into the holocaust of Verdun and Ypres set a sinister precedent, if only for imposing even more unlimited massacres on the enemy' (1997, 256-7). Technology also plays a crucial role. It allows war to escalate beyond belief, and in Finkielkraut's words, sets off an 'endless chain,' which leads to the Russian revolution, the rise of Stalin and Hitler, the Cold War, and so on (Finkielkraut 2000, 6970). The twentieth century is thus an 'endless conflict,' requiring 'total mobilisation,' 'total war' and 'total victory,' a new and startling break with the past (Finkielkraut 2000, 72).

For others, World War II is the nodal point and the defining event of the twentieth century. Lukacs is a particularly strong adherent of this idea. For him, 'much of the 
twentieth century before 1940-41 led up to Hitler.' As well, 'so much of the rest of the century, from 1941 on, was the consequence of the Second World War that he alone had begun and that was dominated by his presence until the end' (Lukacs 1993, 9). Howard and Louis similarly advance World War II as, 'the pivotal event of the century.' The emergence of an 'American century'; the decline of Europe and its old imperial system, and the rise of ideological conflict during the Cold War figure as little more than a denouement (Howard and Louis 1998, xxi). Three decades before, George Steiner, in his critique of T.S. Eliot, termed the post-war era a 'post culture,' with World War II leaving a, 'formidable gap in the co-ordinates of location, of psychological recognition in the western mind' (1972, 55-6). Little seems to have changed since then, despite the collapse of Communism in Europe.

While wars figure as high-water marks in the grim history of the twentieth century, they do not encapsulate the totality of the century's horrors - one must also rely on utilitarian appraisals - statistics and quantitative analysis. In 1993, Brzezinski dissected the century in terms of 'megadeaths,' that is, death tolls of over 10 to the power of six. This includes the two world wars and roughly thirty civil wars with at least ten thousand casualties each. In these cases, civilians suffered the majority of deaths and injuries. Totalitarian ideologies, bent on creating 'coercive utopias,' are for Brzezinski a unique feature of the twentieth century, as is the invention of genocide, specifically the idea of mass killing unrelated to traditional war aims (1995, 8-9). Brzezinski calculates that some 60 million alone died in failed attempts to create Communist utopias, in the Soviet Union, China, and Cambodia. The total number of casualties for the twentieth century is between 167 and 175 million dead, a result, Brzezinski posits, of 'politically motivated carnage' (1995, 11-18). A more recent update by the Carnegie Commission adds another four million casualties since 1989, and includes conflicts in the Gulf, the Horn of Africa, and the Balkans (Jacoby 1999, 168).

What Brzezinski, Hobsbawm, and Glover share is the belief that raw data or quantitative analysis provides the best gauge of a given century's horror. For utilitarian philosophers, the higher the death totals, the worse the century. Judgements of good 
and evil are reducible to a comparison between the numbers of people killed in any given situation. Such a belief allowed Glover to posit earlier in Causing Death and Saving Lives, '[W]hen we think soberly about the worst hypothetical choice in the world, it is hard not to conclude that a Nazi society, including the extermination camps, would be less terrible than a major nuclear war' (1990, 262). Glover offered another scenario, where nuclear war would in fact be the lesser of two evils, 'If you construct an imaginary case in which the only way to stop the leaders of a country releasing a virus that will kill everybody on earth is to wage nuclear war, I will agree that in those circumstances nuclear war would be justifiable’ (1990, 262).

The key issue here is high numbers. The relative horror of an event or potential event is measured largely by the numbers of people killed (and perhaps tortured); morality lies in the minimisation of death and suffering. High casualty rates, when added to the rise of dictatorships, irrational ideologies, technological warfare and the collapse of Enlightenment narratives and Christian morality, produce a century that is seemingly unique in its atrociousness. Or does it?

\section{Colonialism and Imperialism}

The mere exercise of promoting the twentieth century as the worst in history necessarily involves some level of wilful blindness. In order to create a form of dramatic contrast between then and now, the past is presented in glowing colours, involving what Edward Said has called a 'blotting out of knowledge’ (Stannard 1992, 14).

Western and other crimes go back centuries. Stannard's American Holocaust was one of the first books to promote earlier eras as qualitatively and quantitatively worse than the more recent past. Writing in 1992, Stannard advanced that the average rate of depopulation in the Americas since 1492 has been between 90-98 percent, due to a combination of ‘firestorms of microbial pestilence and purposeful genocide’ (1992, xii). Through a mixture of disease, slave labour, massacre and forced resettlement, the death toll from continual orgies of violence was fixed at roughly 100 million people, making 
the destruction of the American Indians, 'far and away, the most massive act of genocide in the history of the world' (Stannard 1992, x).

As well, we need to consider that Spanish crimes in the Americas also reflect events taking place in Spain, from the final defeat of the Moors to the expulsion of the Jews, as Enrique Dussel (1995) and Walter Mignolo (1995; 2005) both discuss. Colonial terror continued in various forms, under various empires, for almost five centuries. The Spanish were responsible for the deaths of tens of millions of indigenous peoples, followed by the British during the sixteenth century and after, who continued the wholesale slaughter of indigenous peoples. The torch was then passed to the United States in the eighteenth century.

Shelley Wright invites us to see that twentieth century horrors like the Holocaust hardly constitute argues, 'a great chasm dividing us irrevocably from our brutal past. It is a very thin line. We have crossed it many times.' The difference between the pre and post-Holocaust world is not that the world has necessarily become any more violent, or evil. Rather, the Holocaust has forced us to 'understand that the violence of ethnic tribalism is not confined to Africa, or Asia, or the Middle East, or the cities of Eastern Europe - it is here, at home - We are the Savage' (Wright 2001, 18-9).

\section{The Nineteenth Century as Pristine}

The nineteenth century is portrayed as the era when the ideals of the Enlightenment were put into practice, namely: 'a universal system of ... rules and standards of moral behaviour, embodied in the institutions of states dedicated to rational progress of humanity' (Hobsbawm 1997, 254). It is also described as a peaceful century, because there were no major wars in Europe until 1914 (Hobsbawm 1994, 22). Hobsbawm's 'long nineteenth century' is relatively mild, since it, 'seemed, and actually was, a period of almost unbroken material, intellectual and moral progress' $(1994,13)$. Violence was uncommon, and events such as the Irish Republican bombing of Westminster Hall, and the pogroms of Russian Jews were, 'small, almost negligible by the standards of modern massacre.' As well, 'the dead were counted in dozens, not hundreds, let alone 
millions' (Hobsbawm 1994, 13). For Brzezinski, there is no doubt that 'The twentieth century was born in hope. It dawned in a relatively benign setting, [with] ... a relatively prolonged spell of peace' $(1995,3)$. While we are presented with the Crimean War, the Franco-Prussian War, and the Russo-Japanese War of 1905, each is dismissed with a banal revisionism. Crimea had, 'no major geopolitical repercussions,' while the other two are cast in an almost positive light, since they 'signalled the emergence on the world scene of Germany and Japan respectively, as new potential major actors’ (Brzezinksi 1995, 3).

One detects a similar outlook with Glover’s first chapter in Humanity, entitled 'Never Such Innocence Again.’ He too describes ‘One hundred years of largely unbroken European peace,' making it, 'plausible to think that the human race was growing out of its warlike past’ $(1990,3)$. The early twentieth century marked, he argues, a belief in moral progress, with, 'human viciousness and barbarism in retreat' (1990, 1). Lukacs's nineteenth century is distinguished by, 'the absence of world war,' thus accounting for its prosperity and progressiveness $(1993,2)$. For Howard and Louis, the nineteenth century emerges as a Golden Age, with the end of the century marking 'the dawn of a new and happier age in the history of mankind,' an age dominated by science and technology, trade, finance, and growing military power $(1998,3)$. Arguably, this Golden Age portrayal of the nineteenth century allows for the creation of a straw man, a sitting target that is soon shot down by historians when Gavrilo Princip fires his fatal Browning pistol.

In the search for a contrast and foil, much of this literature elides the negative realities of colonialism, at best dealing with them in a cursory and superficial fashion. Peace in Europe implies ipso facto that Europeans are peaceful and rational by nature. The application of this idea with regards to colonialism renders a skewed portrait of events. For Howard and Louis, colonialism in Africa and Asia lead to an 'almost unquestioned belief in the cultural and indeed racial superiority of the 'white' races over the rest of mankind' (1998, 3-5). This state of affairs was not necessarily negative, however, since, 'This belief was usually combined with a sense of obligation to bring the blessings of 
'civilization' to 'backward' peoples; an obligation combined with one very much older, to spread the Christian gospel among the heathen' $(1998,5)$. A healthy dose of paternalism, it seems, gives colonialism carte blanche.

Colonialism is also excused on the grounds that it had few negative longterm effects. Howard and Louis argue that 'even where Western imperialism seemed most triumphant, indigenous cultures remained largely intact, making no concession to the conqueror than was strictly necessary.' It is only in the twentieth century that 'Western communications, trade, and technology' undermined 'traditional life-styles,' a trend that also affected Europe (Howard and Louis 1998, 6). Here, colonialism emerges as relatively benign, a shallow and easily rectified form of exploitation. Things only change in the twentieth century, a time when everybody, irrespective of race, shares the same sense of dislocation.

For Brzezinski, previous centuries saw 'explosions of violence,' which might have been intense, violent and bloody outbursts - but were nevertheless 'rarely sustained.' As for slaughter, particularly that of non-combatants, this was, 'directly associated with physical contest and conquest; rarely was it a matter of sustained policy, based on systematized premeditation.' Premeditated killing was rather, 'the twentieth century's gruesome contribution to political history’ (Brzezinksi 1995, 5). Roberts argues that despite famines, and attacks by raiders or conquerors, 'old ways' could be resumed. We are to believe that, 'The warp and weft of daily life and the way people lived through it hardly changes much in predominantly agricultural and pastoral societies and the acceptance of occasional disaster was part of that' (1999, 29). For groups that didn't survive - too bad. Roberts describes them as being 'at a stage of achievement low enough to be called Neolithic if not Paleolithic, and ... very vulnerable’ (1999, 90-102). There is a strong and distasteful sense of historical inevitability here, with certain groups being fated to die out once they were confronted with Western civilisations.

On balance, colonialism, and its close cousin imperialism emerge as both positive and negative forces. Imperialism introduces education, technology, western medicine, and 
Christianity. It also introduces organisation and new concepts of identity (Roberts 1999, 98-9). Genocide, terror, economic exploitation, and other features do not seem to be important enough to merit condemnation; they are par for the course, by-products of the colonial experience. Criticism of imperialism, argues Roberts, often centres on the ‘diatribe’ $(1999,83)$. By establishing a hegemonic discourse about the twentieth century as the worst, Roberts, Gilbert, Howard, Hobsbawm and others have to distort earlier periods of history, excising the ‘dark side’ of the nineteenth century. However, it is only by coming to terms with the nineteenth century and its associated colonial horrors that we can better understand the violence of the twentieth century, a century when the outrages perpetrated in Africa, Asia and elsewhere came back to haunt the countries of Europe.

\section{Darkness From the Past}

Colonialism should and must be counted as an aspect of European degeneracy, and as a potential precedent for later dehumanisation, racism, and warfare. In Death and Deliverance (1994), Burleigh described the long and arduous process of training of SS killers during Germany’s euthanasia programs in the 1930s. Browning's Ordinary Men (1993) similarly describes how killers were created rather than born. The ability to dehumanise an enemy, to destroy life with unmitigated cruelty, had to be learned. And not everyone could assimilate these lessons. So it was with European states coming into the twentieth century. Those who cut their teeth on the Boxer rebellion, or raped the Congo of its human and natural resources, those who had exterminated the Tasmanian Aboriginals or mowed down the Western Canadian Métis with Gattling fire, were not the peace-loving, morally progressive peoples we would like the believe.

An alternative view of the twentieth century, and a plausible one, is to see it as a continuation of the past. 'Communism and Nazism,' after all, 'had their origins deep in $19^{\text {th }}$ century history' (Ponting 1998, 9; 18-19). Racism, ethno-nationalism, eugenics, phrenology, and social Darwinism, all are rooted in nineteenth century racial science and social theory. Little about these ideologies was new or particularly innovative. The innovation lay in the transplantation of colonial violence to the European context. As 
Grenville describes, 'Since the mid-nineteenth century the Europeans had avoided fighting each other for empire, since the cost of war between them would have been of quite a different order' $(1994,5)$. Grenville's analysis touches perhaps on the real reason for stability in Europe, the projection of Western aggression onto outside countries, aggression that was 'crudely proven by his [the coloniser's] capacity to conquer other peoples more numerous than the invading European armies' $(1994,5)$.

Such retrospectives provide a more balanced coverage of the twentieth century than others, since they actually look for the roots of aggression in earlier times, rather than seeing 1914 as a complete break from the past. For those truly looking at nineteenth century precedents, there is little in the twentieth century that is a surprise. In earlier centuries, a greater percentage of people died in European colonies than at any time in the twentieth century, even if the absolute numbers were lower. Arguably, more groups were the victims of successful genocide in the eighteenth and nineteenth centuries than afterwards, despite superior technology and communication. Writing during the 1980s and 1990s, historians and journalists like Tatz, Stannard, and Hochschild have been pushing for recognition of indigenous genocides in Australia, the Americas, Africa, and the Asian subcontinent.

I have briefly touched on Stannard's work, which blames Spanish, British and settler authorities from bringing about what he feels is the largest genocide in world history (Stannard 1992, x; 128-9; 222-3). This follows and precedes a growing literature on colonial crimes in the Americas, including the works of Todorov, Thornton, Sale, and Churchill. Much of this builds on the pioneering work of Richard Drinnon, who thoughtfully laid out the case for genocide in his Facing West: The metaphysics of Indian-hating and empire-building (1980).

Hochschild's King Leopold's Ghost explores the horrific legacies of Belgian colonialism in the Congo, from the foundation of the colony in the 1880s, to the death of the Belgian king in 1910. Hochschild delivers a damning critique of colonialism, positing that Belgium's rule in the Congo brought about the deaths of some 10 million 
Congolese Africans (50 percent of the population), through massacre, disease, forced relocation, and slave labour. While the apogee of the killing occurred from 1890 to 1910, straddling the twentieth century, the Congo genocide was nevertheless a pure product of nineteenth-century colonialism (Hochschild 1999, 225-233). Implicit here was the belief that European countries had the right to exploit Africa to the fullest, particularly if great profits could be gained, in this case from the forced cultivation of rubber. Much of this work is a gripping tale of intrigue and duplicity, with King Leopold taking centre stage, emerging as an ungainly, strutting, conniving paedophile, who succeeds in carving out his kingdom, then maintains and enhances it with deliberate care.

Hochschild's narrative style is full of battles between good and evil: bloodthirsty Belgian soldiers and company officials versus human rights workers and foreign observers. However, Leopold is not alone in his ruthless methods. Hochschild notes that other colonial empires followed relatively the same course of action. Rubber production in French West Africa, Portuguese Angola, and the German Camaroons followed a similar trajectory, with the percentages of dead in these regions also approaching fifty percent $(1999,280)$. More recent work by Le Cour Grandmaison traces links between the mentality and techniques that inspired nineteenth century French colonialism in Africa and the Holocaust (2005).

While involving much lower casualty figures, the genocide of the Australian Aborigines during the eighteenth and nineteenth centuries has provoked much research in recent years. As Tatz has argued, British colonialism was responsible for the deaths of some 95 percent of the Aboriginal population in Australia, and for the complete extermination of the Tasmanian Aborigines. Here the original population were much lower than in the Americas or in the Congo, totalling somewhere between 250,000 and 750,000 at the time of Captain James Cook's arrival in 1788. Whatever the earlier figures, by the 1911, there were less than 31,000 Aborigines alive (Tatz 1999, 6-8). Using the 1948 UN Genocide Convention, specifically Article II as a reference, Tatz cites Australia with at least three acts of genocide $(1999,6)$. 
The work of Tatz (1999), Henry Reynolds (1999), Paul Bartrop (2001), A. Dirk Moses (2001), Robert Manne (2001) and others have provoked a series of “History Wars” in Australia over whether Australia committed genocide against its Aboriginal peoples. A special issue of Aboriginal History (Vol. 1 2001) was also devoted to the topic. Much of the controversy stemmed from a 1997 report produced by the Human Rights and Equal Opportunity Commission, entitled 'Bringing them Home: Report of the National Inquiry into the Separation of Aboriginal and Torres Strait Islander Children from their Families.' The Report, the outcome of a national inquiry commissioned by the Labor government in May 1995, acknowledged that the Australian government had 'knowingly committed genocide through the forcible transfer of children, as a matter of official policy, not just yesteryear but as recently as the 1970s’ (Tatz 1999, 33). However the lack of recognition of the Report's conclusions by the Australian government has further fuelled the "History Wars" over whether the government should apologise for the crimes of the past (MacIntyre 2003).

While studies of indigenous genocides and colonial oppression are arguably becoming a growth industry, the tragic impact of two centuries of British rule in India has been underexplored in recent times. Chomsky (1993) is one of the few Western academics to have made reference to Indian famines, particularly the Bengal famine of 1769-70, which killed an estimated 10 million people. Davis’s Late Victorian Holocausts provides another recent account although he raises the total numbers of dead to 30 million overall, based on statistics from The Lancet (2001, 7-8). While Brzezinski is content to blame ideology and dictators for megadeaths, he has yet to apply his model to earlier colonial periods. Forays into the past present us with new challenges. We are forced to consider the twentieth century not just as one of change and transformation, but also as a time of evolution and inherited moral corruption from the past. Should we acknowledge the reality of past atrocities, history becomes neither a 'surprise,' nor a break from the past. A forum is opened where debate and discussion over the past can come forth. 


\section{Dissecting The Twentieth Century}

If there have been horrors in previous centuries every bit as bad as those in the twentieth, why then do current retrospectives elide the realities of the past? I would offer six key reasons, of potentially many more, why previous centuries have not been deemed worthy of comparison but should be:

1) Twentieth century violence is condemned as irrational, versus the rationality and profit-oriented motives of colonialism.

Retrospectives of the twentieth century often focus on the irrationality of violence, and the rapid, unexpected but inevitable escalation of warfare. It is almost tautological to say that the madness, or bestiality, of the twentieth century consisted in an abandonment of earlier values and norms. The old order was seemingly rational, moral, and Christian; the new order, with its 'arrogantly irrational goals,' its moral nihilism, and its totalitarian ideologies, was not.

However, in condemning the new order as an abandonment of the old, the nineteenth century emerges as a time of rationality, morality and idealism, as does colonialism. In the nineteenth century, J.A. Hobson and Karl Marx would condemn colonialism as oppressive, but would similarly see the rationality behind it: establishing and expanding markets, while bringing about trade monopolies in lesser developed regions. Greed and the quest for profit were and still are seen as inherently rational, as was the quest for exclusive control over regional trade. As Nicholson describes the logic behind this process, 'An obvious way of trying to reduce the risks on investment was to take political control of the area it was in ... imperialism developed to defend and promote economic activity’ (1998, 71-2).

Nostalgia for nineteenth century liberal democracy and free trade often ignores the highly exploitative nature of these systems. For example, the bleeding of India in the eighteenth and nineteenth centuries gave Britain the raw materials and later the markets to fuel its industrial revolution, something for which, Nehru ironically remarked, 'Bengal can take pride.’ Describing British rule as little more than a 'gold lust,' Nehru 
saw the 'liquidation of the artisan class' as directly attributable to the suppression of Indian domestic manufacturing in favour of British imports. This led to the deaths of ‘tens of millions’ of people (Nehru 1990, 209-11). An 1835 British commission of inquiry supposed this claim, noting that, 'the misery hardly finds parallel in the history of commerce. The bones of cotton-weavers are bleaching the plains of India' (Chomsky 1993, 13).

Killing in order to clear land for settlement, or killing and enslavement as a by-product of industrialisation, urbanisation, cultivation, or other aspects of modernity, all emerge as essentially rational but regrettable aspects of the forward march of 'the history of commerce.' Coker has cleverly compared 'Westernisation' in the colonies with nihilism in the West. Both for him perform the same function - they break down traditional cultures, and destroy self-respect $(1998,158)$. As more studies expose the irrationality and brutality of colonialism, our previous conceptions of it will necessarily change.

2) The development of the mass media and the globalisation of information allow us to know about twentieth century atrocities. However, such access to information was not available in earlier centuries, leading to a false impression that 'no news is good news.'

Northrop Frye argued several decades ago that, 'Man has doubtless always experienced time in the same way, dragged backwards from the receding past into an unknown future. But the quickening of the pace of news, with telegraph and submarine cable, helped to dramatize a sense of the world in visible motion, with every day bringing new scenes and episodes of a passing show' $(1967,31)$. The evolution of mass media allows us to know much more about the world than ever before. But with this knowledge comes obligations, as Ignatieff has argued (1998). We have become more attuned to what he calls the 'the needs of strangers,' and these needs can include protection from cruelty and harm. Graphic images from around the world allow people to empathise with one another, reinforcing a sense of global responsibility. The increased demand for humanitarian intervention in such trouble spots as Rwanda, Bosnia, and Kosovo is 
proof positive of this phenomenon (Ignatieff 1998; Mullerson 1997, 28-31).

Today, as it was for much of the previous century, we take it for granted that if something horrible happens, we will find out about it. Should we doubt the objectivity of the mass media, websites and NGOs can keep us informed about human rights violations around the world. Until the twentieth century, the paucity of impartial journalism and mass electronic communication made atrocities difficult to catalogue, if anyone actually cared to learn about them. Many of the details of the past have only come to light in recent years, as demonstrated by the range of contemporary studies. As the weight of historical knowledge about colonial atrocities increases, we will begin to see more patterns going from one century to the next.

3) We expect people to live today, and we have a belief in human equality. It is difficult to understand how attitudes could have been otherwise in previous centuries. With international conventions on human rights and genocide, there is at least a hope that nations will conform to some moral standard of behaviour, and treat their citizens with equal fairness. However, conceptions of universal rights and equality are new largely a reaction to World Wars I and II. Before the last century, when colonialism ran riot throughout much of the world, most indigenous inhabitants were not considered full persons. The 1788 doctrine of terra nullius, for example, declared Australia to be 'a land empty but for fauna and flora.' Aborigines were denied the status of being considered humans until the mid twentieth century (Tatz 1999, 7). Theories of superior and inferior religions, civilisations, and races were crucial in the development of colonialism, and such a sense of superiority legitimated a litany of colonial atrocities: land theft, enslavement, deliberate spreading of disease, and massacre.

As Nicholson argues, 'One hundred years ago, the idea that people of all races and both sexes had equal rights was accepted only by a minority’ (1998, 194). Singer adds that, 'Racist assumptions shared by most Europeans at the turn of century are now totally unacceptable, at least in public life’ $(1979,14)$. With an evolving sense of morality and equality comes a lack of understanding of past conceptions of inequality. While we 
might expect the Interahamwe or Arkan's Tigers to slaughter their enemies with impunity, we don't expect Western leaders to be overtly racist or bloodthirsty. The projection of twentieth century norms on an understanding of past leaders and their motivations obscures the reality of the racial attitudes of earlier époques.

4) Personifying evil is something more common to the twentieth century than in earlier periods of history. We need to be aware that the lack of an evil dictator or totalising ideology does not detract from the horrors of an event.

Discussions of twentieth century evil often involve the personification of it, for example, in the policies, ideology or personal traits of Adolf Hitler, Joseph Stalin, or Mao Zedong. While such personification is possible for twentieth century atrocity, earlier instances of genocide and suffering are much harder to personify in one man or one ideology. Historical characters such as Genghis Khan or Napoleon Bonaparte were the exceptions rather than the rule.

Earlier periods of history were not so simple to understand. Genocide and terror could take place over generations, and often did. With few interested lobby groups or photojournalists to hide from, no international conventions to uphold, no television cameras to avoid, pre-twentieth century killers could afford to take their time. They could be systematic or not, they could choose a variety of methods: disease, army massacres, settler militia patrols, bounties, slave labour, or whatever means seem appropriate. In some countries like Australia and the United States, large numbers of settlers were seemingly eager to do their part in the killing of indigenous peoples, who, at any rate, were denied the status of being fully human. Governments sometimes, but not always, condoned atrocities. The victims of genocide were an inconvenience, a troublesome eyesore, often dying because they seemingly stood in the path of progress and civilisation.

Discussions of past genocides must reject the twentieth century need for figureheads and stereotypes. As Tatz argues, people today have a particular image in mind when they think of genocide, conditioned by the standards of Hitler or Stalin. For many, the 
success of a genocide accusation of genocide depends on the structure and 'look' of the state involved,

\begin{abstract}
Australians understand only the stereotypical or traditional scenes of historical or present-day slaughter. For them, genocide connotes either the bulldozed corpses at Belsen or the serried rows of Cambodian skulls, the panga-wielding Hutu in pursuit of Tutsi victims or the ethnic cleansing in the former Yugoslavia. As Australians see it, patently we cannot be connected to, or with, the stereotypes of Swastika-wearing SS psychopaths, or crazed black tribal Africans (Tatz 1999, 2).
\end{abstract}

In Tatz's definition of genocide, intent is not even necessary, as long as there are sufficient casualties and a high enough percentage of the target population killed (1999, 36). Helen Fein similarly advances that genocide can be the result of, 'sustained purposeful action by a perpetrator to physically destroy a collectivity directly or indirectly’ (Chalk 1994, 49). In the Australian case, there does not have to be a Hitlerlike figure for genocide to have occurred.

A common element of these critiques is their structuralist outlook. Tony Barta has argued for, 'a conception of genocide which embraces relations of destruction and removes from the word the emphasis on policy and intention which brought it into being' (Nicholson 1998, 137). Here it is the system, but not any specific policies or actors, which brings about genocide. One could also adopt Nicholson's distinction between 'somatic violence' and 'structural violence,' somatic being the intentional killing of individuals through war or mass murder. Structural violence on the other hand, 'happens when people die because of the activities of other human beings even though they did not intend to kill them as such’ (Nicholson 1998, 137). 'Unnecessary poverty' figures as an example of this phenomenon. A similar attitude is evident in Stannard's critique (1992). A reading of his work suggests that there are simply too many leaders promoting atrocities, in too many places, and over too long a period for any one man (or woman) to be singled out as an 'anti-Christ.'

Even Hochschild's denunciation of Belgian colonialism does not target Leopold directly for mass murder. His is also a structuralist critique; Leopold maliciously put in place the conditions for a genocide, and it comes to pass. And once the structure was in 
place, other countries such as France, Portugal and Germany followed Belgium’s lead and committed similar atrocities, spurred by the competition for low cost rubber. Nehru's analysis is equally structuralist. Rather than singling out Robert Clive or Queen Victoria, he attacks structures and institutions, namely: British colonialism, the zamindari system, and the industrial revolution. Even in his denunciation of the Viceroy, Nehru is attacking his position in Indian society, and the logic of the colonial system that introduced the office. This emphasis on structure versus individual invariably makes critiques of the past less precise; it reduces the number of exploitable symbols and metaphors, and as Tatz maintains, makes genocide less salient and less understandable.

5) The inability or lack of interest in statistically quantifying the suffering or deaths of non-European groups. No quantum of suffering has been done for the nineteenth or earlier centuries in terms of 'megadeaths.'

In the twentieth century, 'before' and 'after' population statistics (however imprecise) make it relatively easy to estimate the numbers of dead in conflict. Population losses during the Holocaust, ditto those in Cambodia and Rwanda, can be quantified reasonably accurately, even if there is disagreement about specifics. While there is often some covering up of death totals, as in Stalinist Russia or Maoist China, we still have a good idea of how many people died, and when. For political scientists obsessed with quantifying precise totals or calculating precise numbers of 'megadeaths,' the imprecision of previous centuries can be frustrating, leading to a rejection of the reality of past horrors.

While the number of wars in the nineteenth can often be ascertained (Henderson and Tucker 2001, 317-338), casualty rates are not always obvious, especially for nonEuropean combatants. Colonialism often produces slow and steady casualty rates comparable to losses in low to medium intensity conflict. Researchers looking into past genocides must often content themselves with ranges of numbers, rather than precise totals. Tatz, for example, has no accurate figures for the Aboriginal population before Cook's voyages. The range of pre-conquest figures varies from 250,000 to 750,000, 
even though we know that by 1924, only 31,000 remained. Researchers into the Belgal famine must content themselves with a rough estimate of 10 million. Even the total deaths for the 1943 Famine are expressed as a range. As Keay puts it, 'famine fatalities are notoriously unreliable’ $(2001,504)$. Hochschild is in the same boat. To reach his figure of ten million, he has relied on a 1919 official Belgian government commission, who concluded that the population had been 'reduced by half.' However, it was only in 1924 that the first proper census was taken, which gave a figure of ten million survivors (1999, 233).

Stannard's research has also involved a rejection of older, less accurate population totals. These estimates, based on the work of Kroeber and the 'Berkeley School' put the total population of the Americas at less than 15 million (with only 1 million in North America). Stannard therefore privileges Borah and Dobyns, both of whom put the preconquest population of the Americas at well over 100 million. However, even these are dismissed as an underestimation; for him, 'all estimates to date have been too low.' In general, Stannard argues that as archaeological investigation becomes more sophisticated, it will be easier for, 'previous 'invisible’ population loss,' to be discovered (1992, 267-8). Clearly, we will never know precisely how many people perished as a result of colonialism, nor will we ever have completely accurate totals for evaluating population size before European conquest. Nevertheless, there may be anywhere from 20-70 million indigenous casualties in the nineteenth century as a direct result of colonialism in Africa, the Americas, Asia, and the Antipodes. So far, however, no one has attempted a Brzezinski-esque form of quantitative analysis for earlier centuries.

As new information about the past is being unearthed, our view of previous centuries will necessarily change. Hoschchild was the first to systematically prepare a coherent and readable analysis of Belgian genocide in the Congo, yet the information existed for decades. What was lacking was the interest and the will of a competent researcher to put all of the pieces together. While not as accurate as documentation about contemporary atrocities, we should not discount the reality of previous 'megadeaths.' 
Rather, we should understand that that colonial governments who were directly or indirectly responsible for these crimes did not keep accurate statistics for the same reason they killed these people off in the first place; these people did not matter.

6) Wilful blindness, and a lack of desire to tarnish the past can prevent rigorous examination of the negative aspects of colonialism.

Anthony Smith has written much on myths of the Golden Age, something that pervades Western, and indeed, all cultures to one extent or another. Positive myths about a nation's past help to 'define the historic culture community,' while endowing it with a 'particular energy and power' $(1983,152)$. History, argues Smith, forms a 'repository or quarry from which materials may be selected in the construction and invention of nations’ (1997, 37). Further, a nation’s ‘immortality’ is based on its ability to ‘unfold a glorious past, a golden age of saints and heroes, to give meaning to its promise of restoration and dignity' (Smith 1983, 153-4). The desire to preserve a pure and unadulterated sense of national history might be responsible for much of the wilful blindness we see in twentieth century retrospectives.

All nations wish to preserve a positive sense of their own history. While Blake's 'Jerusalem' might be embarrassingly dated for some, a sense of empire as a positive endeavour remains in many historical accounts. As Paxman has argued in The English (1998), there is a certain nostalgia for the forgotten 'Breed,' those who created and maintained the British empire. Such men were presented as 'Fearless and philistine, safe in taxis and invaluable in shipwrecks, ... the embodiment of the ruling class, men you could send to the ends of the earth and know that they would dominate the natives firmly but fairly, their needs no more than the occasional months-old copy of The Times and a tin of their favourite pipe tobacco’ $(1998,177)$.

Most nations have a tendency to gloss over their past, to diminish the negative aspects of their history in the service of national mythology. The twentieth century retrospective is but one example of this process in motion. We are thus left with Howard and Louis’s promise that, 'indigenous cultures remained largely intact,' even 
after centuries of colonial exploitation (Gilbert 1997, 14-5). We also have Brzezinski's hopeful analysis that atrocities in the past were rarely, 'a matter of sustained policy' $(1995,5)$. Perhaps the indigenous peoples of Australia and the Americas would disagree. Protecting his conception of a European Golden Age, Roberts had this to say: 'The dark side of the balance sheet of empire has so often been set out that there is mercifully no need for further elaboration on the many wickednesses it contains' (1999, 90). The key word here is 'mercifully,' suggesting that in commemorating the negative legacies of colonialism we deride the self-esteem of the colonisers, destroying the portrait historians are trying to paint.

\section{Conclusions}

In the final analysis, the nineteenth century, and those preceding it allow us to see the twentieth century as an evolution and an application of earlier forms of behaviour. Our century was not in every sense a break with earlier periods, but was in many respects a continuation of it. While it is much harder to quantify, personify, and document the evils of the past, this does not meant that atrocity, violence, and abject terror did not exist. What we remember and commemorate about the twentieth century, the events we enshrine and pass down to our children will be based on the previous century as the worst ever, the best of times and the worst of times.

Fortunately perhaps, retrospectives carry their own in-built obsolescence. In his analysis of Russian history after 1989, Hobsbawm argued that Cold War-era analyses written in the West, compiled by the piecing together snippets of information from the Soviet Union, were now of little use. With the opening up of the Russian archives we now have almost full access to the 'truth' of what happened during Communism's history. Because of increased information, he argues, 'an enormous mass of literature that appeared during this time will now have to be junked, whatever its ingenuity in using fragmentary sources and the plausibility of its guesswork. We just won't need it anymore.' These books will now provide insight into the historiography of the Soviet era, not its history per se (Hobsbawm 1997, 243). The same can and may well be said about twentieth century chronologies in the not so distant future. What emerges from 
these retrospectives, and a new era of genocide studies, is that there are two very different ideas about previous centuries, and their significance in world history, one that privileges the twentieth century, and another that resurrects the past as an important focus of study.

\section{Reference List}

P. Bartrop, P. 2001, 'The Holocaust, the Aborigines, and the Bureaucracy of Destruction: an Australian Dimension of Genocide,' Journal of Genocide Research, vol. 3, no. 1, 75-87.

Browning, C. 1993, Ordinary Men: Reserve Police Battalion 101 and the Final Solution in Poland, Harper Collins, New York.

Brzezinksi, Z. 1995, Out of Control: Global Turmoil on the Eve of the 21st Century, Touchstone, New York.

Buckley-Zistel, S. 2006, 'Remembering to Forget: Chosen Amnesia as a Strategy for Local Coexistence in Post-Genocide Rwanda,' Africa: The Journal of the International African Institute, vol. 76, no. 2, 131-50.

Burleigh, M. 1994, Death and Deliverance: 'Euthanasia' in Germany 1900-1945, Cambridge University Press, Cambridge.

Campbell, D. 1993, Politics Without Principle: Sovereignty, Ethics and the Narratives of the Gulf War, Lynne Rienner, Boulder, CO.

Chakrabarty, D. 2000, Provincializing Europe: Postcolonial Thought and Historical Difference, Princeton University Press, Princeton.

Chalk, F. 1994, 'Redefining Genocide,' in Genocide: Conceptual and Historical Dimensions, ed. G. Andropoulos, University of Pennsylvania Press, Philadelphia, 47-63.

Chomsky, N. 1993, Year 501: The Conquest Continues, South End Press, Boston.

Coker, C. 1998, Twilight of the West, Westview, London.

Conquest, R. 2000, Reflections on a Ravaged Century, W W Norton \& Company, New York.

Davis, M. 2001, Late Victorian Holocausts, Verso, London.

Drinnon, R. 1980, Facing West: The Metaphysics of Indian-hating and Empire-building, University of Minnesota Press, Minneapolis.

Dussel, E. 1995, The Invention of the Americas: Eclipse of "the Other" and the Myth of Modernity, translated by Michael D. Barber, Continuum, New York.

Finkielkraut, A. 2000, In the Name of Humanity: Reflections on the Twentieth Century, Columbia University Press, New York. 1998, The Future of a Negation: Reflections on the Question of Genocide translated by Mary Byrd Kelly, University of Nebraska Press, London.

Frye, N. 1967, The Modern Century: The Whidden Lectures 1967, Oxford University Press, Toronto.

Gilbert, M. 1997, A History of the Twentieth Century: Volume One: 1900-1933, HarperCollins, London.

Glover, J. 1999, Humanity: A Moral History of the Twentieth Century, Jonathan Cape, London. 1990, Causing Death and Saving Lives, Penguin, London.

Grenville, J.A.S. 1994, A History of the World in the Twentieth Century, Harvard University Press, Cambridge.

Henderson, E. and R. Tucker, 2001, 'Clear and Present Strangers: The Clash of Civilizations and International Conflict,' International Studies Quarterly, vol. 45, no. 2, June, 317-38.

Hobsbawm, E. 1997, On History, Weidenfeld \& Nicolson, London. 1994, Age of Extremes: The Short Twentieth Century 1914-1991, Penguin, London.

Hochschild, A. 1999, King Leopold's Ghost: A Story of Greed, Terror and Heroism in Colonial Africa, MacMillan, London.

Howard, M., and W.R. Louis, eds, 1998, The Oxford History of the Twentieth Century, Oxford University Press, Oxford.

Hynes, S. 1998, The Soldier's Tale: Bearing Witness to Modern War, Pimlico, London.

Ignatieff, M. 2001, Virtual War: Kosovo and Beyond, Vintage, London. 1998, The Warrior's Honour, Chatto and Windus, London.

Jacoby, R. 1999, The End of Utopia: Politics and Culture in an Age of Apathy, Basic Books, New York. 
Judah, T. 1997, The Serbs: History, Myth And The Destruction of Yugoslavia, Yale University Press, New Haven, CT.

Keay, J. 2001, India: A History, Grove, London.

Le Cour Grandmainson, O. 2005, Coloniser, Exterminer: Sur la guerre et l'Etat colonial, Fayard, Paris.

Lukacs, J. 1993, The End of the Twentieth Century and the end of the Modern Age, Ticknor \& Fields, New York.

MacIntyre, S. 2003, The History Wars, Melbourne University Press, Melbourne.

Malcolm, N. 1998, Kosovo: A Short History, MacMillan, London.

Manne, R. 2001, 'In Denial: the Stolen Generations and the Right,' Australian Quarterly Essay, vol.1, 1113.

Margaret, S. 2005, Reckoning with the Past: Teaching History in Northern Ireland Lexington Books, Lanham, MD.

Marriott, J.A.R. 1930, The Eastern Question: An Historical Study in European Diplomacy, Clarendon Press, Oxford.

Mignolo, W. 2005. The Idea of Latin America, Blackwell, Malden, MA.

1995. The Darker Side of the Renaissance: Literacy, Territoriality, and Colonization, University of Michigan Press, Ann Arbor.

Moses, A.D. 2000, 'An Antipodean Genocide? The Origins of the Genocidal Moment in the Colonization of Australia', Journal of Genocide Research, vol. 2, no. 1, 89-106.

Mullerson, R. 1997, Human Rights Diplomacy, Routledge, London.

Nehru, J. 1990, The Discovery of India, Oxford University Press, New York.

Nicholson, M. 1998, International Relations: A Concise Introduction, MacMillan, London.

Paxman, J. 1998, The English: The Portrait of a People, Michael Joseph, London.

Polya, G.M. 1995, 'The Famine of History: Bengal 1943,' International Network on Holocaust and Genocide, vol. 10, 10-15.

Ponting, C. 1998, The 20 $0^{\text {th }}$ Century: A World History, Henry Holt and Company, New York.

Reynolds, H. 1999, Why Weren't We Told? A Personal Search for the Truth about our History, Viking, London.

Roberts, J.M. 1999, The Twentieth Century: The History of the World, 1901 to 2000, Penguin Viking, New York.

Singer, P. 1979, Practical Ethics, Cambridge University Press, Cambridge.

Smith, A. 1997, 'The “Golden Age” and National Revival,' in Myths and Nationhood, eds. G. Hosking and G. Schöpflin, C. Hurst and Company, London, 36-59. 1983, Theories of Nationalism, Holmes \& Meier, New York.

Stannard, D. 1992, American Holocaust: The Conquest of the New World, Oxford University Press, London.

Steiner, G. 1972, In Blue Beard's Castle: Some Notes on the Redefinition of Culture, Yale University Press, New Haven, CT.

Tatz, C. 1999, 'Genocide In Australia,' AIATSIS Research Discussion Papers No. 8.

Todorov, T. 1984, The Conquest of America: The Quest for the Other, Harper \& Row, New York.

White, H. 1987, The Content of the Form: Narrative Discourse and Historical Representation, Johns Hopkins University Press, Baltimore, MD.

Wiesel, E. 1960, Night, Avon Books, New York.

Wright, S. 2001, International Human Rights, Decolonisation and Globalisation: Becoming Human, Routledge, New York. 